\title{
PELATIHAN KETERAMPILAN PEMBUATAN PERHIASAN DARI KAWAT (WIRE JEWELRY DI LINGKUNGAN JEMPONG TIMUR MATARAM
}

\author{
Syamsul Arifin \\ Dosen Prodi. Matematika FTK UIN Mataram
}

\begin{abstract}
Abstrak: Jempong Timur merupakan lingkungan paling padat di wilayah Kelurahan Jempong Baru Kecamatan Sekarbela Kota Mataram. Populasinya mencapai 1.659 jiwa. Dari aspek ekonomi, sebagian besar warganya terbelit masalah kemiskinan. Kondisi ini dipandang sebagai penyebab munculnya stigma lingkungan tersebut sebagai "wilayah hitam" dalam perspektif sosiologis.

Untuk mencapai tujuan tersebut, pelatihan ini dikelola dengan menempuh berbagai strategi pra-pelaksanaan dan pelaksanaan. Strategi pra-pelaksanaan berupa kajian demografi, audiensi dengan pemerintah dan aparat Keluraharan, melakukan pendekatan dan kerja sama dengan pihak-pihak terkait, dan menyusun perencanaan pelatihan berdasarkan analisis kebutuhan personal, serta mempersiapkan materi, bahan, dan sarana pendukung. Sementara strategi pelaksanaan berkaitan dengan model pelatihan yang ditempuh berupa model pelatihan Off The Job Training dengan teknik informasi $30 \%$ dan simulasi $70 \%$.

Dengan strategi tersebut, pelatihan ini berhasil dalam tiga domain, yakni: 1) kognitif: a. peserta mampu menjelaskan jenis-jenis kawat yang digunakan sebagai bahan untuk membuat perhiasan; $b$, peserta mampu menjelaskan fungsi dan kegunaan berbagai jenis kawat dan mampu membedakan antara jenis kawat yang satu dengan kawat lainnya; c, peserta mampu menyebutkan jenis-jenis tang (peralatan) dan mampu menjelaskan kegunaannya; $d$, peserta mampu menyebutkan berbagai bahan yang dibutuhkan dalam pembuatan perhiasan dari kawat sesuai dengan jenis perhiasannya. 2) Psikomotok: Peserta mampu menggunakan tang secara tepat dan benar. Selanjutnya, mereka berhasil membuat perhiasan berupa kalung dari kawat. Namun, hanya enam orang peserta yang mampu membuat perhiasan yang dimaksud dengan kualifikasi sangat baik; 3) Afektif, sebagian peserta memiliki sikap positif berupa sikap kemandirian, kerja sama, sabar, tidak mudah menyerah dan optimis. Keberhasilan mencapai sikap dimaksud terlihat dari keterlibatan mereka selama proses pelatihan berlangsung.
\end{abstract}

Kata Kunci: Pelatihan, keterampilan, Perhiasan, dan Kawat

\section{PENDAHULUAN}

Benar Adanya bahwa Indonesia hingga saat ini belum bebas dari persoalan kemiskinan. Berdasarkan Badan Pusat Statistik, jumlah penduduk Indonesia per September tahun 2016 sebanyak 257,9 juta jiwa ${ }^{12}$ dan 27,76 juta orang (10,70 persen) di antaranya berkategori miskin. ${ }^{13}$ Dari sumber yang sama, di tingkat proponsi Nusa Tenggara Barat, jumlah penduduk miskin per September 2016

\footnotetext{
${ }^{12}$ Deni Setiawan, [01-09-2016] "Data Terkini Penduduk Indonesia 257,9 juta, yang wajib KTP 182.5 Juta", tersedia http://jateng.tribunnews.com [5-4-2017]

${ }^{13}$ Humas Sskab, [3-1-2017]"BPS: Per September 2016, Jumlah Penduduk Miskin Indonesia Berkurang 0,25 Juta" tersedia dalam http://setkab.go.id/[5-4-2017]
} 
sebanyak $16.02 \%$ dari jumlah penduduk 4.896.162 jiwa. Sementara Mataram sebagai ibu kota Propinsi NTB dihuni oleh penduduk sebanyak 459.314 jiwa dan mereka yang berada di garis kesejehateraan terendah sebanyak 81.528 pada tahun $2015^{14}$.

Masalah kemiskinan memang sama tuanya dengan usia kemanusiaan itu sendiri dan implikasi permasalahannya dapat melibatkan berbagai segi kehidupan manusia. Dengan kata lain bahwa kemiskinan ini merupakan masalah sosial yang sifatnya mendunia, artinya masalah kemiskinan sudah menjadi perhatian dunia, dan masalah tersebut ada di semua negara, walaupun dampak dari kemiskinan berbeda-beda. Meskipun demikian, tidak jarang kemiskinan sering tidak disadari kehadirannya sebagai masalah oleh indivdu-individu yang bersangkutan. Bagi mereka yang tergolong miskin, kemiskinan adalah sesuatu yang nyata ada dalam kehidupan mereka sehari-hari karena mereka merasakan hidup dalam kemiskinan. Kesadaran akan kemiskinan akan dirasakan ketika membandingkan kehidupan yang sedang dijalani dengan kehidupan orang lain yang tergolong mempunyai tingkat kehidupan ekonomi lebih tinggi. Hal ini menyulitkan pemerintah ketika akan menentukan penduduk miskin, karena mereka (penduduk) sendiri tidak sadar akan kemiskinannya.

Salah satu solusi kemiskinan menggunakan jalur ekonomi adalah membangun dan menghidupkan industri rumahan (home industry) yang berbasis pada ide-ide kreatif untuk menghasilkan pendapatan. Para pakar ekonomi menyebut kegiatan tersebut dengan istilah "ekonomi kreatif", yakni sebuah "talenta" (baru) yang mengubah kehidupan masyarakat melalui ide/gagasan kreatif, sehingga menghasilkan produk-produk bernilai tambah ekonomi yang mampu menjadikan kehidupan individu mencapai dan atau lebih sejahtera ${ }^{15}$.

Secara sederhana dan sesuai dengan kenyataannya, ekonomi kreatif (creative economy) diartikan sebagai talenta (ide kreatif-inovatif) dengan nilai ekonomi yang mampu merubah kualitas hidup manusia menjadi lebih sejahtera. Ekonomi

\footnotetext{
${ }^{14}$ Badan Pusat Statistik Propinsi Nusa Tenggara Barat, tersedia http://ntb.bps.go.id/linkTableDinamis/[5-4-2017]

${ }^{15}$ Herie Saksono, "Ekonomi Kreatif: Talenta Baru Pemicu Daya Saing Daerah" dalam Jurnal Bina Praja | Volume 4 No. 2 Juni 2012, h. 93
} 
kreatif lebih mengandalkan kreativitas individu melalui gagasan, daya kreasi, dan daya cipta untuk meningkatkan nilai tambah ekonomi karyanya, sehingga mampu menciptakan lapangan kerja dan kesejahteraan ${ }^{16}$.

Ekonomi Kreatif sebagaimana dipahami di atas telah direspon secara resmi oleh pemerintah Indonesia yang ditandai dengan peluncuran Program Ekonomi Kreatif. Langkah pemerintah ini diawali dengan terbitnya Instruksi Presiden Nomor 6 Tahun 2009 Tentang Pengembangan Ekonomi Kreatif. Salah satu isi InPres tersebut adalah Ekonomi Kreatif sebagai program wajib beberapa kementerian/lembaga dan seluruh pemerintahan daerah (provinsi dan kabupaten/ kota). Di samping itu, Presiden juga mencanangkan Tahun 2009 sebagai Tahun Indonesia Kreatif. ${ }^{17}$

Namun, memperhatikan berbagai keterbatasan, Pemerintah menetapkan prioritas pengembangan ekonomi kreatif dalam kurun waktu 2009 - 2014 difokuskan kepada 7 (tujuh) kelompok industri kreatif, yaitu: (1) arsitektur; (2) fesyen; (3) kerajinan; (4) layanan komputer dan piranti lunak; (5) periklanan; (6) permainan interaktif; dan (7) riset dan pengembangan ${ }^{18}$.

Kini, manfaat ekonomi kreatif semakin dirasakan. Peta Industri Kreatif dalam Perekonomian Indonesia Tahun 1020 (Data Global Business Guide Indonesia 2011) menunjukkan andil industri kreatif dalam perekonomian dalam negeri. Menyimak besarnya penyerapan sumberdaya manusia (SDM) yang mencapai \pm 7,5 juta pekerja di subsektor industri kreatif, menandakan besarnya potensi anak negeri bertalenta kreatif. ${ }^{19}$

Melihat peran Ekonomi Kreatif yang sangat positif dalam mengentaskan kemiskinan dan meningkatkan masyarakat sebagaimana tergambar di atas, sangat layak industri rumahan ini terus didukung dan dikembangkan khususnya di daerah-daerah kantung-kantong kemiskinan, seperti d Kelurahan Jempong kecamatan Sekarbela kota Mataram. Salah satu pengembangan Ekonomi Kreatif

\footnotetext{
${ }^{16}$ Ibid., h. 96

${ }^{17}$ Ibid., h. 96

${ }^{18}$ Herie Saksono dalam (http://www.gbgindonesia.com/en/services/ article/2011 /indonesia s_creative_industries.php)

${ }^{19}$ Herie Saksono, Opcit., h. 96.
} 
dapat dilakukan kegiatan pelatihan keterampilan yang dapat mengasah ide-ide cerdas masyarakat. Berdasarkan kebijakan Pemerintah Pusat tentang jenis-jenis Ekonomi Kreatif yang menjadi skala prioritas, fesyen dapat dipilih sebagai sasaran dari program tersebut. Di antara jenis fesyen yang saat ini sedang dikembangkan dalam industri rumahan adalah Perhiasan Dari Kawat atau dikenal dengan sebutan Wire Jewelry.

Mengikuti nalar logis di atas, Penulis tertarik untuk melakukan kegiatan pengabdian kepada masyarakat dalam bentuk Pelatihan Keterampilan Pembuatan Perhiasan Dari Kawat atau Wire Jewelry Di Kelurahan Jempong SekarbelaTimur Mataram.

\section{PEMBAHASAN}

\section{Strategi Yang Dilakukan Untuk Mencapai Kondisi Harapan}

Agar kegiatan pendampingan berjalan dengan baik dan lancar sesuai harapan dan produk kegiatan ini dapat dicapai secara maksimal, maka tim pendampingan mempersiapkan dua strategi, yakni strategi persiapan dan strategi pelaksanaan kegiatan pendampingan dengan penjelasan sebagai berikut:

\section{Strategi Persiapan Kegiatan Pendampingan}

Kegiatan dampingan sudah semestinya dipersiapkan secara matang dengan harapan di samping mendapatkan dukungan maksimal dari semua pihak, khususnya pemerintahan Kelurahan Jempong, juga mendapatkan apresiasi yang memadai dari para calon peserta pelatihan sehingga mereka dapat berpartisipasi secara aktif selama pelatihan berlangsung. Di samping itu, persiapan dilakukan secara matang dengan memperhatikan situasi masyarakat Jempong yang dapat disebut sebagai "masyarakat yang unik" dengan karakteristik-karakteristik yang dimiliki. Langkah-langkah yang ditempuh penuh dengan sikap yang hati-hati menghindari hal-hal yang tidak diinginkan, seperti adanya miskomunikasi dan kriminal oleh orang-orang atau individu-individu dari masyarakat Jempong. Untuk maksud tersebut, tim melakukan beberapa strategi atau langkah-langkah sebagai berikut: 
Transformasi, Vol. 13, No. 1, Januari 2017: 44 - 61

a) Melakukan kajian demografi secara sederhana tentang Keluarahan Jempong Baru. Diketahui bahwa Jempong Baru merupakan salah satu Keluarahan yang berada di wilayah Kecamatan Sekabela Kota Mataram. Kelurahan Jempong Baru memiliki wilayah yang sangat luas, terdiri dari 12 lingkungan di antaranya Kodiasri, Jempong Barat, dan Jempong Timur. Sebagian wilayah Jempong Baru terdiri dari daerah perumahan, seperti daerah kodiasri, tapen dan lain-lain.

Lingkungan Jempong Timur merupakan daerah perkampungan di tengah kota Mataram. Kelurahan ini termasuk lingkungan terpadat di Kelurahan Jempong Baru. Jumlah populasi penduduknya mencapai 1.569 jiwa. Sebagian besar dari Mereka menamatkan pendidikan hanya pada tingkat Sekolah Dasar. Rendahnya tingkat pendidikan mereka berdampak pada rendahnya tingkat kesejahteraan. Selain itu, mereka tidak memiliki keterampilan yang memadai. Akibatnya, sebagian besar dari mereka menjadi Kusir Cidomo dan buruh pasar. Selebihnya orang dewasanya bekerja setabutan dan pengangguran. Dilihat dari aspek ekonomi, Lingkungan Jempong Timur menjadi kantong kemiskinan kota sekaligus menjadi sarang kriminalitas.

Namun, dibalik gambar buram di atas, Lingkungan Jempong Timur memiliki keistimewaan yang boleh jadi tidak dimiliki oleh lingkunganlingkungan lain di kelurahan Jempong Baru atau di kelurahan lainnya. Di antara keistimewaan tersebut adalah Gerakan Subuh Berjemaah yang dipeloporori oleh organisasi Remaja Masjid Jempong Barat dan Jempong Timur yang bernama "PEMUDA JEMPONG BERSATU". Mereka adalah para pemuda terdidik masyarakat Jempong Timur dan Jempong Barat. Sebagian dari mareka sudah bergelar Sarjana S-1 dan Lulusan UIN Mataram dan Perguruan Tinggi yang berada di kota Mataram.

Hasil kajian demografis tersebut di atas dijadikan acuan bagi Tim untuk menyusun dan melakukan perencanaan berikutnya. Berdasarkan kajian demografi tersebut, Tim membatasi wilayah sasaran kegiatan hanya pada tingkat lingkungan bukan tingkat Kelurahan/desa. Pembatasan didasarkan 
pada pertimbangan efektivitas kegiatan dan analisis kebutuhan dasar. Tim melihat bahwa Timur Jempong dipandang lebih membutuhkan pembinaan daripada lingkungan-lingkungan lain yang berada di wilayah kelurahan Jempong Baru. Akhirnya, Tim menetapkan Masyarakat Jempong Timur sebagai sasaran kegiatan.

b) Melakukan audiensi dengan pemerintah Kelurahan Jempong Baru kecamatan Sekarbela kota Mataram, khususnya, kepala Kelurahan Jempong Baru, Kepala Lingkungan Jempong Barat, Tim penggerak PKK Kelurahan dan Pengurus Pemuda Jempong Bersatu. Audiensi ini dilakukan dengan tujuan untuk memberitahukan dan menjelaskan maksud dan tujuan diadakannya kegiatan pendampingan ini berikut jenis-jenis program yang akan dilakukan. Dengan langkah ini, kegiatan pendampingan diharapkan mendapatkan sambutan positif dan dukungan dari semua pihak sehingga kegiatan pendampingan dapat berjalan sesuai harapan.

c) Identifikasi peserta. Mengingat besarnya jumlah keluarga di Kelurahan Jempong Baru Sekarbela Kota Mataram sehingga tidak mungkin semua semua warga Jempong Barat menjadi peserta pelatihan, maka sebelum melakukan kegiatan pendampingan, Tim Pendampingan terlebih dahulu melakukan identifikasi terhadap warga lingkungan akan menjadi peserta dalam kegiatan tersebut. Sesuai dengan jenis dan karakter kegiatan pendampingan yang akan digelar, berupa pembuatan perhiasan dari kawat, yang akan dijadikan subyek dampingan adalah warga lingkungan dengan karakteristik sebagai berikut: (1) tidak memiliki pekerjaan tetap; (2) tidak sedang menyusui dan memiliki bayi; (3) kalangan remaja, pemuda, dan dewasa, baik laki-laki atau perempuan; (4) tidak atau sedang mengenyam pendidikan; (5) memiliki minat belajar dan mengembangkan kemampuan membuat perhiasan dari kawat. Dengan karakteristik tersebut, Tim berharap mereka yang akan mengikuti pelatihan adalah individu-individu yang memiliki minat yang kuat, sudah mempunyai kemampuan dasar dalam membuat perhiasan dari kawat, dan mampu mengikuti pelatihan dengan serius dan tuntas, akhirnya, mereka betul-betul memiliki 
kemampuan untuk membuat perhiasan dari kawat. Indikatornya adalah setiap individu dari mereka sebagai peserta berhasil membuat perhiasan dari kawat yang layak pakai.

d) Menjalin kerjasama dengan instansi terkait, seperti Departemen Koperasi Kota Mataram. Kerja sama ini dilakukan untuk mendapatkan dukungan, terutama berkaitan dengan tindak lanjut kegiatan ini. Selanjutnya, kerja sama juga dilakukan dengan Kepala Kelurahan Jempong Sekarbela Kota Mataram, Tim penggerak PKK, tokoh agama masyarakat, tokoh masyarakat setempat, dan Pengurus Pemuda Jempong Bersatu. Langkah ini dilakukan dengan tujuan kegiatan pelatihan ini mendapatkan dukungan secara maksimal sehingga pelatihan dapat berjalan dengan sukses dan lancar tanpa hambatan. Dari Lurah Kelurahan Jempong Baru, Tim Pendampingan berharap mendapat dukungan berupa adanya tempat pelatihan yang memadai berikut dengan akomodasi selama pelatihan berlangsung, seperti sonsystem, MCK, tempat sholat dan tersedia air untuk berwudlu'. Di samping itu, Kediaan Lurah untuk mengundang aparat Kelurahan lainnya, termasuk Kepala Lingkungan Jempong Baru untuk hadir dalam rapat persiapan dan pada acara pembukaan pelatihan.

Kepada Kepala Lingkungan Jempong Timur, Tim berharap adanya kesediaan dari yang bersangkutan untuk mempublikasikan kegiatan pelatihan ini kepada masyarakat dan mengajak mereka untuk mengikuti kegiatan tersebut. Kepada Pemuda Jempong Bersatu, Tim berharap kepada mereka untuk membantu melakukan mobilisasi massa (penjemputan dan pemulangan peserta) ke dan dari lokasi pelatihan. Harapan ini penting ditekankan mengingat tempat pelatihan ini berada di kantor Kelurahan Jempong Baru. Jarak tempuh Lingkungan Jempong Timur ke lokasi tersebut kurang lebih 1.5 km. Untuk datang ke lokasi, peserta harus berkendaraan agar dapat sampai di lokasi tepat waktu. Untuk menghindari ketidakhadiran atau keterlambatan peserta karena alasan jarak tempuh, maka dilakukan strategi penjemputan yang dilakukan oleh pihak Pemuda Jempong Bersatu. Di samping itu, Pemuda Jempong Bersatu diharapkan mampu mensosialisasikan pelatihan berikut 
dengan karakteristiknya dan jumlah peserta maksimal 50 orang. Dengan strategi seperti itu, peserta pelatihan mewujud seperti karakteristik yang ditetapkan dan mereka dapat mengikuti kegiatan terhambat oleh kendala transportasi.

Selain bekerja dengan berbagai pihak di atas, Tim juga bekerja sama dengan Calon Nara Sumber pelatihan dalam mendisain pelatihann sesuai karakteristik pelatihan berikut bahan dan materi yang harus dipersiapkan sehingga pelatihan dapat berjalan secara produktif dengan menghasilkan produk-produk yang jelas. Pembiacaran yang detail tentang disain, bahan dan materi pelatihan penting dilakukan antara Tim dan Calon Nara Sumber karena tim sama sekali tidak kemampuan di bidang pembuatan perhiasan. Tim hanya bertindak sebagai penyelenggara kegiatan. Kesamaan visi dan konsep pelatihan antara Tim dan calon Nara Sumber sekaligus sebagai instruktur mutlak dibutuhkan.

Pihak lain lagi yang diajak kerja sama oleh Tim adalah mahasiswa. Mereka dilibatkan dalam kegiatan pelatihan ini sebagai bagian dari pendidikan bagi mereka malam pengabdian di masyarakat.

\section{Strategi Pelaksanaan Kegiatan Pendampingan}

Strategi ini berkaitan dengan tujuan kegiatan pelatihan, yakni peserta pelatiham mampu membuat perhiasan dari kawat secara sederhana berupa Bros, Kalung, Gelang dan cincin yang terbuat dari kawat. Namun, dengan mempertimbangkan durasi waktu yang disediakan, yakni dua hari atau $2 \times 7$ jam, maka target yang hendak dicapai melalui kegiatan pelatihan ini ada dalam tiga ranah, yaitu: 1) kognitif: a. peserta dapat menjelaskan jenis-jenis kawat yang digunakan sebagai bahan untuk membuat perhiasan; $b$, peserta dapat menjelaskan fungsi dan kegunaan berbagai jenis kawat dan mampu membedakan antara jenis kawat yang satu dengan kawat lainnya; c, peserta dapat menyebutkan jenis-jenis tang (peralatan) dan mampu menjelaskan kegunaannya; $d$, peserta mampu menyebutkan berbagai bahan yang dibutuhkan dalam pembuatan perhiasan dari kawat sesuai dengan jenis perhiasannya. 2) Psikomotok: Peserta mampu menggunakan tang secara 
Transformasi, Vol. 13, No. 1, Januari 2017: 44 - 61

tepat dan benar. Pengertian secara tepat mengandung arti satu jenis jenis tang tertentu hanya untuk kawat tertentu. Sedangkan yang dimaksud menggunakan secara adalah kesesuaian antara tujuan penggunaan tang dengan jenis tang yang digunakan Selanjutnya, mereka berhasil membuat perhiasan berupa kalung dari kawat; 3) Afektif, peserta memiliki sikap positif berupa sikap kemandirian, kerja sama, sabar, ulet dan optimis. Keberhasilan mencapai sikap dimaksud terlihat dari keterlibatan mereka selama proses pelatihan berlangsung.

Untuk mencapai tujuan dengan jabaran secara ditail tersebut ada beberapa langkah yang ditempuh dengan uraian sebagai berikut:

a) Membuat petunjuk pelaksanaan (Juklak) pelatihan dan Jadwal Kegiatan yang memadai. Di dalam Juklak ini, terdapat kisi-kisi materi berikut target tujuan setiap materi, bahan dan strategi pelatihan, termsuk yel-yel "pelatihan seperti kami bisa, kami sejahtera, kami berguna".

b) Penyajian Materi Pelatihan. Langkah ini dilakukan dengan tujuan peserta pelatihan dapat memahami materi pelatihan secara memadai. Untuk memaksimalkan pencapaian tujuan tersebut, materi disajikan dengan menggunakan power point melalui layar proyektor LCD dan bahasa yang sederhana dan mudah dicerna, serta didukung metode dialogis dan demontratif. Di samping itu, penyajian materi disertai dengan media yang mendukung, seperti photo-photo perhiatan, jenis-jenis kawat, dan jenis tang. Selain photo, media pendukung yang ditampilkan berupa video-video langkah-langkah pembuatan perhiasan dari kawat.

c) Praktik membuat perhiasan dari kawat secara secara perorangan dalam kelompok. Strategi ini dilakukan untuk menumbuhkan dan mengasah keterampilan dimaksud sehingga mereka betul-betul bisa membuat perhiasan tersebut. Untuk memaksimalkan praktik dilakukan pendampingan secara personal. Praktik pembuatan perhiasan dilakukan secara bertahap: 1) praktik pengenalan jenis kawat dan tang; 2) praktik langkah-langkah awal pembuatan perhiasan, seperti cara memegang kawat dan memegang 
tang; 3) praktik melilit kawat; 4) praktik membuat perhiasan Kalung terbuat dari kawat.

d) Melakukan reinforcement (memberikan penguatan) berupa bahasa verbal maupun non berval. Tujuan dari inforcement adalah peserta semangat dalam mengikuti kegiatan dan berkarya.

e) Setelah praktik, dilakukan evaluasi hasil praktik mereka latihan. Hasil evaluasi atau penilaian dijadikan dasar untuk melakukan praktik berikutnya. Selanjutnya, seperti yang dapat menghasilkan karya terbaik diapresiasi dengan memberikan penghargaan berupa perhiasan dari kawat dan bahanbahan tambahan untuk kegiatan praktik di rumah mereka.

Dengan strategi yang terurai di atas, pelaksanaan pelatihan dapat berjalan efektif sehingga tujuan yang diharapkan dapat diwujudkan dengan mudah.

\section{Hasil Pendampingan}

Tujuan utama kegiatan pelatihan adalah peserta pelatiham mampu membuat perhiasan dari kawat secara sederhana berupa Bros, Kalung, Gelang dan cincin yang terbuat dari kawat. Namun, dengan mempertimbangkan durasi waktu yang disediakan, yakni dua hari atau $2 \times 7$ jam, maka target yang hendak dicapai melalui kegiatan pelatihan ini ada dalam tiga ranah, yaitu: 1) kognitif: a. peserta dapat menjelaskan jenis-jenis kawat yang digunakan sebagai bahan untuk membuat perhiasan; $b$, peserta dapat menjelaskan fungsi dan kegunaan berbagai jenis kawat dan mampu membedakan antara jenis kawat yang satu dengan kawat lainnya; c, peserta dapat menyebutkan jenis-jenis tang (peralatan) dan mampu menjelaskan kegunaannya; $d$, peserta mampu menyebutkan berbagai bahan yang dibutuhkan dalam pembuatan perhiasan dari kawat sesuai dengan jenis perhiasannya. 2) Psikomotok: Peserta mampu menggunakan tang secara tepat dan benar. Pengertian secara tepat mengandung arti satu jenis jenis tang tertentu hanya untuk kawat tertentu. Sedangkan yang dimaksud menggunakan secara benar adalah kesesuaian antara tujuan penggunaan tang dengan jenis tang yang digunakan Selanjutnya, mereka berhasil membuat perhiasan berupa kalung dari 
kawat; 3) Afektif, peserta memiliki sikap positif berupa sikap kemandirian, kerja sama, sabar, ulet dan optimis. Keberhasilan mencapai sikap dimaksud terlihat dari keterlibatan mereka selama proses pelatihan berlangsung.

Dua jenis kesuksesan, yakni keberhasilan pelaksanaan kegiatan dan keberhasilan mencapai tujuan karena faktor-faktor pendukungnya bekerja secara efektif. Faktor-faktor yang dimaksud antara lain adalah Pihak-pihak yang terlibat dalam pelatihan dapat bekerja secara efektif.

Pemerintah Kelurahan Jempong Baru kecamatan Sekarbela kota Mataram telah memberikan bantuan yang luar biasa berupa penyediaan tempat pelatihan yang memadai berikut dengan akomodasi selama pelatihan berlangsung, seperti sonsystem, MCK, tempat sholat dan tersedia air untuk berwudlu'. Di samping itu, Lurah juga turun tangan untuk mengundang aparat Kelurahan lainnya, termasuk Kepala Lingkungan Jempong Baru untuk hadir dalam rapat persiapan dan pada acara pembukaan pelatihan. Selain lurah, Kepala Lingkungan Jempong Barat juga berperan dalam mempublikasikan kegiatan pelatihan ini kepada masyarakat dan mengajak mereka untuk mengikuti kegiatan tersebut. Kiprah Kepala Lingkungan Jempong Barat didukung oleh Tim penggerak PKK Kelurahan.

Komponen lain yang berperan vital adalah Pengurus Pemuda Jempong Bersatu. Mereka membantu melakukan mobilisasi massa (penjemputan dan pemulangan peserta) ke dan dari lokasi pelatihan. Peran mereka sangat vital mengingat tempat pelatihan ini berada di kantor Kelurahan Jempong Baru. Di samping itu, Pemuda Jempong Bersatu berhasil mensosialisasikan pelatihan berikut dengan karakteristiknya dan jumlah peserta maksimal 50 orang. Dengan strategi seperti itu, peserta pelatihan mewujud seperti karakteristik yang ditetapkan dan mereka dapat mengikuti kegiatan terhambat oleh kendala transportasi.

Faktor lainya yang membuat kegiatan pelatihan ini berhasil adalah peserta pelatihan sesuai dengan karakteristik yang ditetapkan, yakni Warga Kelurahan Jempong Baru Sekarbela Kota Mataram dengan karakteristik sebagai berikut: (a) tidak memiliki pekerjaan tetap; (b) tidak sedang menyusui dan memiliki bayi; (c) kalangan remaja, pemuda, dan dewasa, baik laki-laki atau perempuan; (d) tidak 
atau sedang mengenyam pendidikan; (e) memiliki minat belajar dan mengembangkan kemampuan membuat perhiasan dari kawat.

Nara Sumber pelatihan juga menjadi komponen strategis sebagai teman diskusi tim dalam mendisain pelatihan sesuai karakteristik pelatihan. Di samping itu, Nara sumber berperan dalam menentukan bahan dan materi yang harus dipersiapkan sehingga pelatihan dapat berjalan secara produktif dengan menghasilkan produk-produk yang jelas. Pembiacaran yang detail tentang disain, bahan dan materi pelatihan penting dilakukan antara Tim dan Nara Sumber memastikan bahwa materi dan bahan yang dipersiapkan sesuai dengan kebutuhan pelatihan. Pada tahap ini, Tim hanya bertindak sebagai penyedia bahan dan penyelenggara kegiatan. Kesamaan visi dan konsep pelatihan antara Tim dan calon Nara Sumber sekaligus sebagai instruktur mutlak dibutuhkan. Di samping itu, dia juga telah menjalankan tugasnya sebagai intruktur dengan baik. Pihak lain lagi yang diajak kerja sama oleh Tim adalah mahasiswa. Mereka dilibatkan dalam kegiatan pelatihan ini sebagai bagian dari pendidikan bagi mereka malam pengabdian di masyarakat.

Dapat ditegaskan bahwa pelaksanaan pelatihan berjalan dengan lancar hampir tanpa kendala. Dikatakan demikian, karena kendala yang menyertai palatihan bukan sesuatu yang serius sehingga mudah teratasi. Solusi yang ditempuh untuk beberapa kendala dapat dilakukan dengan mudah. Misalnya, terkait dengan sempitnya ruangan, pengabdi mengatur kembali formasi kursi dan menggeser posisi layar projector yang bisa terbaca oleh peserta; (2) panasnya ruang pelatihan diatasi dengan membuka semua daun jendela dan menyakan kipas angin; (3) terkait keterlamabatan peserta, pengabdi minta Pengurus Pemuda Jempong Bersatu untuk menjemput mereka kembali.

Pelatihan pembuatan perhiasan dari kawat berorientasi kepada kemampuan, pengetahuan, keterampilan dan sikap seperta pelatihan. Penyataan ini merujuk pada penjelasan Wexley dan Yulk yang berbunyi "Training and development are terms reffering to planned efforts designed facilitate the acquisition of relevant 
Transformasi, Vol. 13, No. 1, Januari 2017: 44 - 61

skill, knowledge and attituteds by organizational members." ${ }^{20}$ Bahwa Pelatihan dan pengembangan merupakan istilah-istilah yang berhubungan dengan usahausaha berencana, yang diselenggarakan untuk mencapai penguasaan skill, pengetahuan, dan sikap-sikap pegawai atau anggota organisasi. Anggota yang dimaksud adalah anggota masyarakat, yakni warga Jempong Timur.

Dari penjelasan di atas, tersirat bahwa tujuan pelatihan ini bergerak dalam tiga domaian, yakni kognitif, afektif dan psikomotorik. Ketiga domain tersebut merupakan inti dari sumber daya manusia. Di sisi yang lain, pelatihan ini memiliki tujuan umum dan tujuan khusus. Kategori tujuan ini berdasar pada penjelasan Notoatmodjo bahwa ada dua macam tujuan pelatihan, yakni Tujuan umum merupakan rumusan tentang kemampuan umum yang akan dicapai oleh pelatihan tersebut dan Tujuan khusus merupakan rincian kemampuan yang dirumuskan dalam kemampuan khusus. ${ }^{21}$ Tujuan umum dari pelatihan ini adalah untuk meningkatkan sumber daya manusia warga Jempong Timur, sedangkan tujuan khususnya adalah untuk mentrasformasikan pengetahuan tentang pembuatan perhiasan dari kawat (kognitif); mewujudkan kemampuan dalam pembuatan perhiasan dari kawat (psikomotorik); dan mengembangkan soft skill atau karakter positif, seperti kemandirian, kerja sama, sabar, ulet, dan kreatif.

Penentuan jenis dan tujuan pelatihan didasarkan pada hasil analisis kebutuhan pelatihan. Menurut Notoatmodjo ${ }^{22}$ ada tiga analisis kebutuhan pelatihan, yaitu:

Pertama, Analisis Organisasi. Analisis Organisaasi pada hakikatnya menyangkut pertanyaan-pertanyaan di mana atau bagaimana di dalam organiasasi atau institusi ada personel yang memerlukan pelatihan. Setelah itu dipertimbangkan biaya, alat-alat, dan perlengkapan yang dipergunakan. Kemudian dilakukan analisis iklim organisasi, sebab hal ini akan berpengaruh terhadap keberhasilan suatu program pelatihan sebagai hasil dari analisis iklim organisasi dapat diketahui kebutuhan-kebutuhan pelatihan. Aspek lain dari analisis organisasi

${ }^{20}$ Soekidjo Notoatmodjo, Pengembangan Sumber Daya Manusia, (Jakarta: PT. Rineka Cipta, 2009), h. 18

${ }^{21}$ Ibid., h. 22.
${ }^{22}$ Ibid., h. 25. 
ialah penentuan berapa banyak karyawan yang perlu dilatih untuk tiap-tiap klasifikasi pekerjaan. Cara-cara untuk memperoleh informasi-informasi ini ialah melalui angket, wawancara atau pengamatan.

Kedua, Analisis Pekerjaan (Job Analysis). Analisis Pekerjaan antara lain menjawab pertanyaan, apa yang harus diajarkan atau diberikan dalam pelatihan agar para karyawan yang bersangkutan mampu melakukan pekerjaan secara efektif. Tujuan utama analisis tugas ialah untuk memperoleh informasi tentang :

1. Tugas-tugas yang harus dilakukan oleh karyawan

2. Tugas-tugas yang dilakukan pada saat itu

3. Tugas-tugas yang seharusnya dilakukan, tetapi belum atau tidak dilakukan karyawan

4. Sikap, pengetahuan, dan keterampilan yang diperlukan untuk melakukan pekerjaan dengan baik, dan sebagainya.

Ketiga, Analisis Pribadi. Analisis pribadi menjawab akan pertanyaan, siapa membutuhkan pelatihan dan pelatihan macam apa. Untuk hal ini diperlukan waktu untuk mengadakan diagnosis yang lengkap tentang masing-masing personel mengenai kemampuan-kemampuan mereka. Untuk memperoleh informasi ini dapat dilakukan melalui achievement test, observasi, dan wawancara.

Jika merujuk pada pandangan Notoatmodjo di atas, maka jenis dan tujuan pelatihan Pembuatan perhiasan ini lebih cenderung secara relatif didasarkan pada hasil analisis pribadi. Dikatakan demikian, karena penentuan jenis dan tujuan pelatihan ini melalui proses diagnosa yang relatif lengkap tentang kemampuan individu-individu warga Jempong Timur melalui observasi dan wawancara.

Agar tujuan yang telah ditetapkan mudah dicapai, maka Tim memilih metode pelatihan yang tepat. Menurut Notoatmodjo, metode pelatihan terbagi menjadi dua yaitu pelatihan di luar pekerjaan (off the job training) dan pelatihan di dalam pekerjaan (on the job training). ${ }^{23}$

Pertama, Pelatihan Di Luar Tugas (Off The Job Training), Pelatihan dengan menggunakan metode off the job training ini berarti individu sebagai peserta pelatihan ke luar sementara dari pekerjaannya. Kemudian mengikuti pelatihan

\footnotetext{
${ }^{23}$ Ibid., h. 32.
} 
Transformasi, Vol. 13, No. 1, Januari 2017: 44 - 61

guna meningkatkan pengetahuan dan keterampilannya dengan menggunakan teknik-teknik belajar mengajar sebagaimana lazimnya.

Selanjutnya, dikatakannya bahwa pada umumnya metode off the job training ini mempunyai dua macam teknik, yaitu teknik presentasi informasi dan teknik simulasi. Notoatmodjo ${ }^{24}$ merumuskan kedua macam teknik ini, bahwa teknik presentasi informasi ialah menyajikan informasi, yang tujuannya mengintroduksikan kemampuan, pengetahuan, sikap dan keterampilan baru kepada para peserta. Harapan akhir dari proses pengetahuan, sikap dan keterampilan perserta diadopsi oleh peserta dalam pekerjaannya nanti. Yang termasuk ke dalam teknik ini adalah :1) Ceramah biasa, 2) Teknik diskusi,3) Teknik permodelan perilaku (behavior modeling),4) Teknik magang.

Adapun teknik simulasi adalah suatu peniruan karakteristik atau perilaku tertentu dari dunia riil sedemikian rupa, sehingga para peserta pelatihan dapat merealisasikan seperti keadaan sebenarnya. Dengan demikian, maka apabila para peserta pelatihan kembali ke tempat pekerjaan semula akan mampu melakukan pekerjaan yang disimulasikan tersebut. Metode-metode simulasi ini mencakup : 1) Studi kasus (case study), 2) Permainan peran (role playing). 3) Teknik di dalam keranjang (in basket).

Kedua, Pelatihan Di Dalam Tugas (On The Job Training. Pelatihan ini berbentuk penugasan-penugasan pegawai-pegawai di bawah bimbingan supervisor yang telah berpengalaman (pegawai senior). Para pegawai senior yang bertugas untuk membimbing pegawai baru diharapkan memperlihatkan contohcontoh pekerjaan yang baik, dan memperlihatkan penanganan suatu pekerjaan yang jelas dan konkret, yang akan dikerjakan oleh pegawai baru tersebut segera setelah pelatihan berakhir.

Mengikuti dua kategori jenis metode pelatihan di atas, Tim pelaksana pelatihan menggunakan metode Pelatihan Di Luar Tugas (Off The Job Training). Hal ini didasarkan bahwa kegiatan pelatihan ini tidak berkaitan dengan pekerjaan peserta pelatihan, baik di rumah maupun di instansi, tempat mereka bekerja. Di

\footnotetext{
${ }^{24}$ Ibid., h. 25.
} 
samping itu, teknik-teknik yang digunakan selama pelatihan berlangsung berupa teknik informasi dan simulasi. Teknik informasi dipilih untuk memaksimalkan terjadinya proses transformasi pengetahuan selama pelatihan berlangsung. Sementara teknik simulasi dipilih untuk memudahkan terwujudnya tujuan utama pelatihan, yaitu peserta mampu membuat perhiasan dari kawat dan terus dikembangkan di tempat (rumah) mereka masing-masing.

Disain pelatihan sebagaimana terjabar di atas membuah hasil sesuai harapan. Kegiatan pelatihan dinyatakan sukses dalam dua sisi pelatihan, yakni sukses pelaksanaan dan sukses mencapai tujuan. Kesuksesan pertama berdasarkan kriteria dan kesuksesan kedua terwujudnya produk sebagai hasil uji coba. Kebenaran penilaian kesuksesan pelatihan ini merujuk pada pendapat Goldstein and Buxton menyatakan.. the evaluation of training centers arround two interacting concerns : 1) The establishment of measures of succes (criteria); and 2) The experimental designs used in the evaluation. 125

Keberhasilan pelatihan ini dapat dilihat dalam tiga domain, yakni: 1) kognitif: a. 42 orang dari 50 peserta aktif mampu menjelaskan jenis-jenis kawat yang digunakan sebagai bahan untuk membuat perhiasan; b, 42 orang dari 50 orang peserta mampu menjelaskan fungsi dan kegunaan berbagai jenis kawat dan mampu membedakan antara jenis kawat yang satu dengan kawat lainnya; c, 42 orang dari 50 orang peserta aktif dapat menyebutkan jenis-jenis tang (peralatan) dan mampu menjelaskan kegunaannya; d, 40 orang dari 50 peserta mampu menyebutkan berbagai bahan yang dibutuhkan dalam pembuatan perhiasan dari kawat sesuai dengan jenis perhiasannya. 2) Psikomotok: 39 orang dari 50 Peserta aktif mampu menggunakan tang secara tepat dan benar. Pengertian secara tepat mengandung arti satu jenis tang tertentu hanya untuk kawat tertentu. Sedangkan yang dimaksud menggunakan secara benar adalah kesesuaian antara tujuan penggunaan tang dengan jenis tang yang digunakan. Selanjutnya, 42 orang dari 50 peserta aktif $\mathrm{m}$ berhasil membuat perhiasan berupa kalung dari kawat. Namun,

\footnotetext{
${ }^{25}$ Anwar Prabu Mangkunegara, Perencanaan \& Pengembangan Sumber Daya Manusia (Bandung: PT Refika Aditama, 2003), h. 69.
} 
Transformasi, Vol. 13, No. 1, Januari 2017: 44 - 61

hanya enam orang peserta yang mampu membuat perhiasan berupa kalung dengan kualifikasi sangat baik; 3) Afektif, sebagian peserta (87\%) memiliki sikap positif berupa sikap kemandirian, kerja sama, sabar, ulet dan optimis. Keberhasilan mencapai sikap dimaksud terlihat dari keterlibatan mereka selama proses pelatihan berlangsung.

\section{KESIMPULAN}

Pelaksanakan pelatihan pembuatan perhiasan dari kawat didesan sesuai dengan teori-teori pelatihan dan berdasarkan hasil analisis penelitian yang memadai. Sesuai dengan teori Stimulus-Respon, respon peserta (baca warga Jempong Timur) sangat kuat, tampak dari wajah yang berseri-seri dan ketekunan dalam bekerja saat praktik pembuatan perhiasan, sebagai bukti bahwa wujud pelatihan ini berhasil menjadi stimulus sehingga mampu menghadirkan optimisme baru dalam hidup mereka - baca warga Jempong Timur yang dalam perspektif sosiologis sarat dengan stigma negatif. Rasa haus dan dahaga yang melilit "tenggorokan" kehidupan mereka selama ini serasa sirna sesaat dengan simple training ini.

Respon positif peserta di atas sebagai modal awal yang sangat berharga dalam mewujudkan subuah the training that meaning full. Untuk mengarah ke arah tersebut, selain respon positif, konsep pelatihan mulai dari perencanaan, pelaksanaan dan evaluasi terjabar dengan jelas dan terukur mutlak dibutuhkan. Inilah kata kunci atau kay word keberhasilan sebuah pelatihan.

Keberhasilan pelatihan ini - jika boleh dikatakan demikian - salah faktornya adalah adanya perencanaan, termasuk dalam menetapkan tujuan pelatihan disusun berdasarkan analisis kebutuhan personal dan dilaksanakan dengan model pelatihan off the job training serta didukung dengan teknik informasi dan simulasi. Selanjutnya, pelaksanaan pelatihan tersebut diakhiri dengan evaluasi yang didasarkan pada tersedianya pengukuran keberhasilan yang jelas dan produk yang dihasilkan. 
Syamsul Arifin, Pelatihan Keterampilan pembuatan...

\section{DAFTAR PUSTAKA}

Abu Huraerah, Pengorganisasian Dan Pengembangan Masyarakat. Model Dan Strategi Pembangunan Berbasis Masyarakat. Bandung : Humaniora, Penerbit Buku Pendidikan - Anggota IKAPI.

Agus Suryono, Pengantar Teori Pembangunan, Malang : UMM Press, 2004.

Badan Pusat Statistik Propinsi Nusa Tenggara Barat, tersedia http://ntb.bps.go.id/linkTableDinamis/[5-4-2017].

Deni Setiawan, [01-09-2016] "Data Terkini Penduduk Indonesia 257,9 juta, yang wajib KTP 182.5 Juta", tersedia http://jateng.tribunnews.com [5-4-2017].

Herie Saksono, "Ekonomi Kreatif: Talenta Baru Pemicu Daya Saing Daerah" dalam Jurnal Bina Praja | Volume 4 No. 2 Juni 2012

Humas Seskab, [3-1-2017]"BPS: Per September 2016, Jumlah Penduduk Miskin Indonesia Berkurang 0,25 Juta" tersedia dalam http://setkab.go.id/[5-42017].

Mangkunegara, Anwar Prabu, Perencanaan \& Pengembangan Sumber Daya Manusia, Bandung: PT Refika Aditama, 2003.

Notoatmodjo, Soekidjo, Pengembangan Sumber Daya Manusia, (Jakarta : PT. Rineka Cipta, 2009)

Siti Ida Nurjannah dalam Journal. Volume 04 Nomor 01 Tahun 2015 Periode Pebruari, 2015 